\title{
Human Security 15 Years after Lysøen: The Case against Drone Killings
}

\author{
Astri Suhrke
}

\begin{abstract}
The concept of human security has evolved in two directions: (1) a comprehensive vision of security and development, and (2) a concretization of the concept tied to protection of civilians in armed conflict. This article discusses the two approaches and their relative merits. Starting with the Lysøen Declaration of 1998 and Canada's subsequent introduction of the concept of human security in the Security Council, the article argues that a concretization is necessary today. One way to do this is to link human security to campaigns for protection of civilians against the U.S. use of drones in targeted killings outside recognized war zones. This strategy would revitalize human security as a relevant policy concept, and also create greater security for people living in exposed communities.
\end{abstract}

Keywords human security, international humanitarian law, foreign policy, Canada, Norway, U.S. drones

\section{Introduction}

Since it was launched in the early 1990s, the concept of human security has evolved in two distinct directions. In one direction, the concept has retained its original general nature, but the notion of "freedom from threat" in a security sense has been added to "freedom from want" in the development sense that was at the core of the original idea presented by the United Nations Development Programme (UNDP) in 1994. The report by the Commission on Human Security in 2003, a decade after the UNDP report, marked the revitalizing of the concept in its general and broad form. The other road traveled has been quite different. Here human security has served as an umbrella, but the political energies of its supporters have been directed towards concretizing and defining some of the elements sheltering under it in ways that could produce policy action and change in practice. The Canadian initiatives in the late 1990s that placed "protection of civilians" as an item under human security on the Security Council agenda is a 
case in point.

This article discusses the two approaches to human security and their relative merits, arguing that concretization is necessary to bring a sharper vision forward. One way to concretize and revitalize the concept at the present historical juncture, it is further argued, is to link it to current campaigns for protection of civilians, such as the campaign opposing the U.S. use of drones for targeted killings outside recognized war zones. This strategy would not only help keep the concept alive, but also create greater security for people living in exposed communities.

In line with this argument, this article has two thematic parts. The first discusses the origins of the concept of human security and, in some detail, its first significant concretization in the United Nations. This concretization focused on protection of civilians, as introduced by Canada in the Security Council. The second thematic section examines the subsequent evolution of the concept. The dominant trend has been to stress the comprehensive and general nature of human security, as exemplified by the Commission on Human Security (UN 2003). In contrast to this focus, the article suggests the alternative of concretization, developed with reference to security against illegal killing. The analysis here discusses drone killings as a distinctly contemporary threat to human security, which, as practiced by the United States, violates the rights of individuals to protection against extra-judicial execution.

\section{The Origins}

Human security originated as a broad development concept, elaborated in the UNDP's Human Development Report of 1994, only four years after the first report was launched. The series was the brainchild of Mabub al Haq, who was also the principal author of the 1994 report (UNDP 1994). The 1994 report was one of the more important and positive outcomes of the competitive dialogue between the World Bank and the UNDP, as reflected in the way human security was defined: In response to the Bank's emphasis on economic growth as the goal of development, Mabub al Haq dialectically positioned individual welfare as the key objective and offered human security as its conceptual derivative. The definition was broad, the parameters defined only as freedom from want/fear and freedom to basic entitlements (ibid., 22-23).

Four years later, at the end of 1998, human security was inserted into the discourse of the UN Security Council. This may not seem so strange today, but at the time it was a radical development. The new element in the discourse meant that the Security Council could focus on the security of individuals rather than of nations as in its traditional mandate. The change set up a potential confrontation with the principle of national sovereignty-arguably the most hallowed principle in the UN system. Moreover, it elevated humanitarian matters to the sphere of 
high politics.

How and why did this happen? The simple answer is-the Canadians. The Canadian government was at the time campaigning for one of the rotating seats on the UN Security Council, and it needed an agenda. Securing a seat on the Security Council, as we know, is a major and intensely competitive enterprise. Canada campaigned on a platform of three themes; the first of these was to integrate human security into the agenda of the Council. ${ }^{1}$ Canada won the seat, and for two calendar years (1999-2000) was successful in placing human security on the Council's agenda. It is a testimony to the importance of that initiative that subsequently human security was routinely and regularly discussed in the Council.

In retrospect, it is clear that human security was a perfect theme for the Canadian campaign for several reasons. First, it elevated a discourse that was already becoming prominent in international aid and humanitarian communities. The term itself invested humanitarian issues with the significance attached to the word "security," and inserting it into the Security Council agenda meant humanitarian questions would henceforth be on the single most important table in the UN system. We now take it for granted that the Security Council regularly discuss issues such as protection of civilians in armed conflict, humanitarian access, accountability under international humanitarian law, and so on. This was not the case until the Canadians used human security to pry open the door. Second, human security resonated with Canadian national politics and a recently established dimension of Canada's international image. What better way to launch your candidacy than under the banner of "security with a human face," a concept befitting a nation where humanitarianism and peacekeeping had long been important foreign policy objectives. Finally, human security would become another element in bilateral cooperation between Canada and Norway to enhance their profiles internationally in matters of peacekeeping and humanitarian affairs. This cooperation dates back to the so-called Oslo-Ottawa axis formed by Halvard Lange and Lester Pearson in the late 1950s and extending into the early 1960s.

The Norwegian government was a supportive player of Canada's early campaign for human security, as evidenced by its hosting the meeting that led to the Lysøen Declaration in May 1998. Lysøen was one of the early platforms for Canada's Security Council bid, and Norway's hosting role reflected similar aspirations. Angling for a seat on the Security Council for the term following Canada's (2001-2002), the Norwegian government was preparing the ground and cultivating friends. The Norwegian campaign focused on strengthening the Council's role in conflict management generally, ${ }^{2}$ but human security was certainly compatible with this line as well as attractive in itself (Fermann 2000). Norway, like Canada, had a foreign policy profile that stressed humanitarianism, peacemaking, and loyalty to the United Nations. A new coalition government had come to power in 1997 led by the Christian Democratic Party, which had a 
particularly strong commitment to aid and humanitarian issues. After Canada was elected to the Security Council, the Canadian delegation expressed its appreciation for the supportive work done by Norway, and there was some expectation that if Norway won a seat in 2001 (which it did), it would carry the torch after Canada.

The above presentation, admittedly, owes much to a neo-realist theoretical approach to understanding international relations. I developed this interpretation further in an article published in 1999, entitled "Human Security and the Interests of States" (Suhrke 1999), but I recognize now more clearly that the sharp realist edge calls for some modification.

Neo-realist interpretations emphasize that states are driven by interests rather than by ideals, and that power is central in defining interests (including the power that comes with a rotating seat on the Security Council). This perspective needs to be balanced by an appreciation of why states define their interests in particular terms. Why human security and not other concepts? The context gives part of the answer. Generally, the 1990s were known as "the humanitarian decade," suggesting an international order with humanitarianism embedded in the language and values of international politics. As noted above, these values harmonized with traditional foreign policy values in both Canada and Norway. In Canada, a liberal government (with both small and large "L") had come to power with a progressive policy agenda, and a forceful foreign minister, Lloyd Axworthy, had taken charge of foreign policy. As one participant in the new government wrote, it was an "extraordinarily fruitful time in Canadian foreign policy." ${ }^{3}$ In other words, the concept of human security was launched with a genuine commitment and distinct idealism; it was much more than a campaign slogan to get Canada onto the Security Council (McRae and Hubert 2001).

Yet it remains striking that noble ideas apparently need to be propelled forward by more robust interests of power and ambition (such as getting a seat on the Council). In 1999, that combination got human security on the Security Council agenda, enriched-and indeed shifted - the political discourse and expanded the inventory of humanitarian practices. Subsequently, however, the concept lost much of its punch. An intergovernmental network was established, but, except for Japan, no country really promoted human security as a central foreign policy objective. In Canada, a later government closed down the human security website. As of 2013, the term was not a subject heading among the eight main categories listed on the website of the Ministry of Foreign Affairs and a quick search revealed only 105 citations of the term (with the most recent in 2004). In Norway, the Ministry of Foreign Affairs similarly does not list human security as a subject heading on its (English language) website, and a search yielded only 37 references in the period 2004-2012. By contrast, a similar review of the website of the Japanese Ministry of Foreign Affairs produced 2,022 references in the English version, and 6,085 times in Japanese (International 
Studies Quarterly 2012).

How do we explain the demise of a normative concept that once appeared so powerful? We have to consider both the context and the concept.

\section{Context and Concept}

Has the global political context changed to make humanitarian language less attractive and relevant? The global context certainly changed after 2001. The United States announced a "global war on terror" (that is still continuing) and, with support of its major allies, invaded two states: first Afghanistan (in 2001) and then Iraq (in 2003). These wars and the related violence perpetrated by the adversaries dominated much of the policy discourse of the first decade of this century. At the UN, the discourse now spoke of insecurity and new threatsthreats from terrorism on a global scale, from drug smuggling and human trafficking, from piracy and epidemics. These and other threat scenarios were laid out by a high-level report requested by the Secretary-General in mid-decade (UN 2004). But parallel, and partly in response, was a new surge in humanitarian activism promoted by prominent activists (also called humanitarian hawks by their critics). This type of activism was evident in many forms and fora. One strand focused on military interventions for ideal ends, but there was also support for difficult humanitarian operations (e.g., in the Darfur), as well as for important institutional developments. The International Criminal Court (ICC), established in 2002, was one such institutional innovation; concepts and principles regarding the Responsibility to Protect (R2P) also received a measure of endorsement by the UN World Summit in 2005; and the UN formally recognized the importance of peacebuilding by establishing the Peacebuilding Commission in the same year.

What happened to human security in this surge of activism to promote human rights and humanitarian concerns? It did not become a conceptual umbrella or flagship for any strand of the new activism. Instead it was appropriated by the broader development community, as well by smaller communities with specialized agendas.

To understand why this happened we need to go back to 1999 and Canada's role in the Security Council. Human security was initially presented as a policy vision - a general sense that the individual rather than the nation should be at the heart of that which is to be secured, as Lloyd Axworthy said at a second Lysøen meeting in 1999 (DFAT 1999). But a policy vision requires conceptual clarification if it is to be taken seriously as an objective of foreign policy. Political leaders who are asked to line up behind a positive slogan will want to know what it entails. A concerned public will wonder if it is more than a slogan. Analysts inside and outside government need to assess whose interests are being served, and what the likely consequences will be-whether intended or not. 
The Canadians worked hard to give human security such a focus and clarity after taking its seat on the UN Security Council in January 1999. At that time, it was still unclear exactly what human security meant, and ideas were bouncing around. I was present at a meeting in Ottawa, in February 1999, where some academics (including myself) and government officials from Norway and Canada met for what was effectively a brainstorming session to flesh out the meaning of human security. I am not sure the meeting produced great results, but a specific agenda soon emerged from the team around Lloyd Axworthy. The agenda had three main components: support for R2P, the ICC, and protection of civilians. Canada initially developed R2P outside the UN through a commission, and, as noted above, the concept received the UN imprimatur in 2005. As for the ICC, the task in 1999 was to get a sufficient number of ratifications to ensure that the Rome Treaty went into effect. That number was reached in 2001. The third element of human security-protection of civilians-was pursued at the Security Council. Let us look more closely at this item.

The first concrete issue under the human security umbrella that Canada placed on the Security Council agenda was protection of civilians during armed conflict. Canada initiated the first open discussion in the Council on this subject as early as February 1999, and by way of follow-up requested a report from the Secretariat. The Secretary-General's report on protection of civilians duly appeared in September that year (UN 1999). It was a comprehensive assessment of the problems ("challenges" in UN language), the responses in terms of law and practice, and recommendations (40 in all). It was the very first thematic report of this kind by the UN. Previous Secretary-General reports to the Council on related themes had focused on countries or missions (although there had been one humanitarian thematic report on refugees, not surprising given that this was a UN mandate subject). But from 1999 onwards things changed. The once novel practice of open discussions in the Security Council on protection of civilians was institutionalized. A biannual report from the Secretary-General on protection of civilians became the occasion for a regular, open Security Council discussion of the subject. In addition, debates addressed particular subthemes, such as children and women in armed conflict. Security Council resolutions came to focus on various aspects of protection of civilians. By 2013, the initiatives had multiplied and specialized websites monitored the process. ${ }^{4}$

In retrospect, it is clear that the two initiatives in 1999-the first Security Council discussion and the Secretary-General's report-were pathbreaking, although it should be noted that Canada kept up the pressure the following year with similar requests for an open discussion, a resolution, and a report from the Secretary-General. In this way continuity was assured and momentum maintained. The term "human security" did not appear in the first Council debate or in the Secretary-General's report, and infrequently in later ones. Rather, the Canadian strategy was evidently to use human security as a legitimizing 
platform from which particular humanitarian initiatives could be launched. To gain traction, these initiatives needed to be concretized and properly wired, so to speak. Protection of civilians was one such initiative which enabled the UN and other concerned actors to address a set of distinct humanitarian problems in political, legal, and practical terms.

Other initiatives were launched from the human security platform. In addition to R2P, the sub-cluster on protection of women and children in armed conflict owes something to the concept of human security; so to some extent does the whole peacebuilding sector. In the world of academe and think tanks, it is telling that a research institute which has incorporated "human security" in its name and whose annual Human Security Report is widely referenced, has likewise sharpened and concretized its work by focusing on one core element: organized violence. The report (published in Canada) tracks global and regional trends in organized violence, their causes and consequences. ${ }^{5}$

By contrast, where human security was promoted as a comprehensive framework-when the platform itself with multiple items became the policyit had little apparent impact. The best example of this is the Commission on Human Security, whose report was published in 2003. The Commission was composed of eminent international personalities and produced a solid report. But the scope was so broad as to be unfocused. The report returned to the strategy of its UNDP predecessor, the 1994 Human Development Report, by adopting a broad development focus - freedom from want and freedom from threats, in part linked to the UN-defined Millennium Development Goals:

Human security is concerned with safeguarding and expanding people's vital freedoms. It requires both shielding people from acute threats and empowering people to take charge of their own lives. Needed are integrated policies that focus on people's survival, livelihood and dignity, during downturns as well as in prosperity (UN 2003, iv).

As a general vision, focusing on "people's survival, livelihood and dignity" was laudable, but the novelty of the vision had faded, and, as a policy initiative, it was too broad to be very useful. The Report was barely cited and has left few traces. It is indicative that a search of the website of the Norwegian Ministry of Foreign Affairs for the term "human security" for the period 2004-2012 showed no reference at all to the Commission's report. By contrast, there were three references to the annual report from the Canadian think tank on human security that publishes annual data on organized violence. As with the protection of civilians and other initiatives launched earlier from the Canadian platform, organized violence was a sufficiently concretized and actionable focus to catch the attention of policy makers. 


\section{The Present Juncture}

If a sharpening of focus is required to translate vision into action, we should ask: What are the most relevant forms in which human security manifests itself at present?

One place to start is a focused survey of the Norwegian Ministry of Foreign Affairs website for the years 2004-2012 conducted by the author. In this period, "human security" was referenced 37 times, mostly in speeches by the minister (32 times); the rest were in press releases, official reports, and similar documents. The frequency is remarkably low. About four citations a year is not a lot, particularly considering all the speeches a foreign minister makes. Moreover, human security was most frequently used as a general term (10 times), without further specification of meaning. The second most frequent use of the term was in relation to arms control or nuclear weapons ( 8 citations); several of these marked the 10th anniversary of the Mine Ban Treaty. The other categories of concretization, which all occurred with even less frequency, were global health, environment (climate change), gender equality, and transnational crime (human trafficking). Human security as protection of civilians was mentioned only two times in these nine years, and human security as R2P only once.

The low frequency notwithstanding, the various concretized derivatives of the broader human security vision are promising. It shows that the concept still has the vitality to inspire, legitimize and empower, while concretization provides the focus and relevance necessary for policy and practice. Not on the list-at least at the time of the survey-was a problem that has received increased attention in 2013-2014, namely state-executed targeted killings outside recognized zones of armed conflict by means of unmanned aerial vehicles (UAVs), or drones. Placing protection against such violence under the human security umbrella would build on the dimension that was successfully introduced in the Security Council in the late 1990s: physical security and protection of civilians in armed conflict. It would further add the equally important element: rule of law. Both dimensions frame the controversial practice by the United States of using drones for what many legal analysts consider to be extra-judicial executions abroad.

Sophisticated drone technology has dramatized the profoundly problematic nature of targeted killings outside clearly recognized war zones. Such killings are certainly not new (most infamously, perhaps, Leon Trotsky was killed while in exile in Mexico by a Stalinist agent wielding an ice axe). But drones enable states (and non-state actors) to deliver death from a safe distance, with a mechanical apparatus that is rarely seen, only heard, by those on the ground. One can imagine the possibilities. Drones are now designed the size of a small bird, like the sparrow-sized flying object that a Norwegian company in 2012 delivered to British forces in Afghanistan. These sparrows are used only for surveillance-as 
yet. The bigger ones used by the United States carry rockets aptly named "Hellfire" and "The Grim Reaper."

Three states at present acknowledge that they carry out targeted killings by various means: Israel, Russia, and the United States. The Russian Parliament even passed a law in 2006 specifically permitting the President to authorize targeted killings against designated individuals abroad. In the United States, the debate inside and outside Congress was growing in 2013, with demands for oversight and transparency in the use of drones. The United States arguably possesses the most sophisticated means-in the form of the latest version of drones-and has certainly targeted the largest number of victims. Although the U.S. government provides no official data, the deaths are in the thousands. In Pakistan alone, CIA drone strikes killed over 2,000 persons in the period 2004-2012, and possibly closer to 4,000 (Bureau of Investigative Journalism 2012). U.S. drone strikes have also targeted and killed individuals in Yemen and Somalia, and in 2013 the Pentagon was establishing a drone base in Niger to carry out strikes in northwest Africa (Whitlock 2013).

Importantly, unlike Afghanistan, these areas are outside what is customarily considered "zones of armed conflict." Consequently, legal scholars and respected institutions-including several UN Special Rapporteurs, the American Civil Liberties Union (ACLU), and Human Rights Watch-have claimed that these killings are clearly illegal, amounting to extra-judicial killings under international human rights law. Since 2002, all UN Special Rapporteurs on extra-judicial executions have condemned targeted killings outside strictly defined zones of armed conflict as illegal. The two most recent rapporteurs, Philip Alston and Christof Heyns, have been especially engaged. In 2012 the UN Special Rapporteur on counter-terrorism and human rights, Ben Emmerson, began actively pursuing the matter, threatening UN investigations of U.S. strikes. As these drone attacks are mostly executed by the CIA, the nomination of John Brennan as CIA director, in February 2013, generated significant public attention about the issue in the United States (Finn and Blake 2013; U.S. Senate 2013).

The case was laid out with great clarity in 2010 by the then UN Special Rapporteur on extra-judicial executions, Philip Alston (UN 2010). As Alston noted, one body of international law covers legitimate, but not arbitrary, killings in war zones (international humanitarian law), and a separate, though partly overlapping, corpus of law covers killing outside such zones (human rights law). Outside war zones (or what legal scholars prefer to call "zones of armed conflict") taking life on purpose without judicial proceedings amounts to extrajudicial executions and is illegal under international law. This does not include legitimately taking life in self-defence, or to spare another life (the so-called "law enforcement model"), where the immediate purpose is to protect, not to take, life. However, the targeted killings practiced by the United States and Israel outside generally recognized war zones have the immediate and explicit purpose of 
taking life, as in an execution.

The practice started under the Bush Administration, but the Obama Administration has been carrying out targeted killings of this kind at a quickening pace since 2008. The drawing up of a "kill-list" in the White House every Tuesday, as reported in 2012, perfectly expresses the purpose (Becker and Shane 2012). If the targets are in what under prevailing international legal standards would be considered a war zone, the actions could be legal, depending upon whether the target is a combatant or a civilian. In Afghanistan, the only clear case of "armed conflict" where the United States has been engaged during this period, the definition of "combatant" is extremely broad and not in line with prevailing legal interpretations: drug dealing if verified by two witnesses could land a person on the list (UN 2010). Outside war zones, as defined by a significant body of international legal experts (e.g., in Pakistan), targeted killings are of questionable legality, although the Obama Administration has plead selfdefence with reference to the 2001 attacks on the United States. Moreover, socalled signature strikes have been used both inside and outside war zones to target categories of persons (e.g., men of military age) rather than an identified individual, raising serious concerns about obligations under international law to discriminate between civilians and combatants (ICRC 2009).

Growing pressure on the Obama Administration to bring practices in line with prevailing standards of international law appear to have had limited effect. In early 2012, the Administration drew up tighter guidelines for targets outside war zones. Reportedly, under these rules, the target would have to represent a "continuing, imminent threat to U.S. persons," and there had to be "near certainty" there would be no civilian (i.e., non-combatant) casualties (Baker 2013). Equally important, President Obama announced, in a widely noted speech on May 23, 2013, that the "war on terror," which had provided Washington with the justification for killing suspected terrorists wherever they were in the world, must come to an end (Obama 2013). He did not say, however, that this openended, undeclared war had actually come to an end, and made clear that targeted killings with drones would continue. The guidelines drawn up in early 2012, and later signed by the President, have remained classified and there is no clear timetable as to when they would go into effect. By early 2014, there was only a plan to "transition to these standards and procedures over time." The part of the plan that envisaged shifting drone operations from the CIA to the Pentagon, and thus increasing transparency, was on a particularly long time-schedule; the plan for this transitioning was to be reviewed every six months (Mazzetti 2014). Congressional critics and human rights activists have noted that little has changed in terms of oversight, accountability, and transparency. Public information about who has been targeted, when, where and why, and related casualties, has remained virtually nil.

The relevance of a human security perspective to address and modify these 
practices is obvious, particularly in relation to protection of civilians. Despite the technological sophistication of drones, "collateral damage" appears to be significant (Stanford Law School and NYU School of Law 2012). The best public figures available for Pakistan, for instance, show that of the 2,300 persons killed by CIA drone strikes in the period 2004-2012, at least 464 were civilians (Bureau of Investigative Journalism 2012). This suggests a ratio of 1 in 5 victims as civilians (women, children, old men). It is questionable if this meets a reasonable interpretation of proportionality and discrimination under international humanitarian law. Moreover, the U.S. government has alternatively obfuscated and manipulated the legal basis for its targeted killings; drew a veil of secrecy around the procedures for determining lists of targets as well as assessments of how many, and who, were killed; refused to provide compensation to civilian, innocent victims; and refused to permit investigation and monitoring of the practice. The result has been "the displacement of clear legal standards with a vaguely defined licence to kill and the creation of a major accountability vacuum," as Philip Alston put it (UN 2010, 1). What is at stake, then-beyond the lives lost and property damaged-is the rule of law. Alston's successor, Christof Heyns, hardly exaggerated when he claimed that drone strikes threaten the very fabric of international law that has been developed through such effort since World War II (Bowcott 2012).

Rule of law is foundational for human security. Given the probability that a number of other states and non-state actors are likely to acquire drone technology and may well want to use it in the not-so-distant future, developing an international, law-based regime for regulating the use of drones is urgent. A proliferation of self-issued licences to kill by states or militant movements operating throughout the world is truly a frightening prospect.

\section{Conclusion}

This dismal prospect presents an opportunity to make the concept of human security relevant to genuine and immediate security needs in the early 21 st century. The UN has developed impressive regulatory regimes to address several categories of vulnerable people, including refugees, displaced persons, child soldiers, and, more generally, civilians in situations of armed conflict. Developing a law-based regime with accountability provisions for targeted killings, particularly with drones, is a logical next item on the list. By early 2014, some work in this direction was underway within the UN system. Invoking human security in support of such initiatives would increase their legitimacy and international appeal. 


\section{Notes}

1. Canada's other two themes were strengthening peacekeeping and making the work of the Security Council more transparent.

2. Norway campaigned on three issues: (1) strengthen UN's capacity to prevent and resolve conflicts, (2) strengthen coordination of UN agencies dealing with conflict management, and (3) create more transparency and better consultation between the Security Council and the other UN units.

3. Paul Heinbecker, Canadian UN ambassador 1999-2000, in communication to the author, February 17, 2013.

4. For example, see http://www.securitycouncilreport.or g/monthly-forecast/2013-02/ protection_of_civilians.php (accessed March 15, 2013).

5. See the website of Human Security Report Project: http://www.hsrgroup.org.

6. In 2005, the International Law Association asked, in its Committee on the Use of Force, to examine the meaning of war or armed conflict in international law. This step was provoked by the U.S. claim of the right to exercise belligerent privileges under law to conduct strikes against suspected terrorists in countries with which, or in which, the United States was not at war. Five years later the Committee delivered its report. It found that in law (as also in political science) the criteria for armed conflict (or war) were a degree of (1) organization and (2) intensity over time. Isolated incidents did not constitute armed conflict or war (International Law Association 2010).

\section{References}

Baker, Peter. 2013. "In Terror Shift, Obama Took a Long Path." New York Times, May 27.

Becker, Jo, and Scott Shane. 2012. "Secret 'Kill List' Proves a Test of Obama’s Principles and Will." New York Times, May 29.

Bowcott, Owen. 2012. "Drone Strikes Threaten 50 Years of International Law, Says UN Rapporteur." The Guardian, June 21.

Bureau of Investigative Journalism. 2012. "Get the Data: Drone Wars. Pakistan Drone Statistics Visualized.” July 2. http://www.thebureauinvestigates.com/2012/07/02/ resources-and-graphs/ (accessed March 15, 2013).

DFAT (Department of Foreign Affairs and Trade of Canada). 1999. "Axworthy Announces Progress on Human Security Agenda." DFAT No. 117, May 20. http://www3. sympatico.ca/ideabank/ksk/News/990520_dfait.html (accessed August 6, 2014).

Fermann, Gunnar. 2000. "Norge i FNs sikkerhetsråd. Muligheter og risiki” [Norway's Role in the Security Council. Possibilities and Risks]. Unpublished paper. http://www.svt. ntnu.no/iss/Kursplaner/Norge_i_Sikkerhetsr\%C3\%A5det.PDF (accessed March 15, 2013).

Finn, Peter, and Aron Blake. 2013. "John Brennan Confirmed as CIA Director, but Filibuster Brings Scrutiny of Drone Program.” Washington Post, March 7. http:// www.washingtonpost.com/politics/rand-paul-says-hes-satisfied-with-obama- 
administrations-response-on-drones/2013/03/07/9b20aa44-875d-11e2-98a3b3db6b9ac586_story.html (accessed July 31, 2014).

ICRC (The International Committee of the Red Cross). 2009. "Interpretive Guidance on the Notion of Direct Participation in Hostilities under International Humanitarian Law." Geneva: ICRC. http://www.icrc.org/eng/resources/documents/publication/ p0990.htm (accessed March 15, 2013).

International Law Association. 2010. "Use of Force: Final Report on the Meaning of Armed Conflict in International Law." Presented to the Hague Conference 2010. http://www. ila-hq.org/en/committees/index.cfm/cid/1022 (accessed March 15, 2013).

International Studies Quarterly. 2012. "Middle Powers' Identities and Interests: What Compels Countries to Promote Human Security?” Manuscript reviewed anonymously for International Studies Quarterly. On file with author.

Mazzetti, Mark. 2014. "Delays in Push to Refocus C.I.A. from Drone Wars.” New York Times, April 6.

McRae, Robert G., and Don Hubert, eds. 2001. Human Security and the New Diplomacy: Protecting People, Promoting Peace. Montreal: McGill-Queens University Press.

Obama, Barack. 2013. "Remarks of President Barack Obama." White House Press Office, May 23. http://www.whitehouse.gov/the-press-office/2013/05/23/remarks-presidentbarack-obama (accessed July 31, 2014).

Stanford Law School and NYU School of Law. 2012. "Living under Drones: Death, Injury and Trauma to Civilians from US Drone Practices in Pakistan." http://www. livingunderdrones.org/wp-content/uploads/2013/10/Stanford-NYU-Living-UnderDrones.pdf (accessed March 15, 2013).

Suhrke, Astri. 1999. "Human Security and the Interests of States." Security Dialogue 30 (3): 265-276.

UN (United Nations). 1999. "Report of the Secretary-General to the Security Council on the Protection of Civilians in Armed Conflict." September 8. S/1999/957. http:// www.un.org/Docs/sc/committees/sanctions/s99957.pdf (accessed July 31, 2014).

UN. 2003. "Human Security Now." New York: Commission on Human Security. http:// reliefweb.int/sites/reliefweb.int/files/resources/91BAEEDBA50C6907C1256D1900 6A9353-chs-security-may03.pdf (accessed July 31, 2014).

UN. 2004. "A More Secure World: Our Shared Responsibility." High Level Panel on Threats, Challenges and Change. New York: United Nations.

UN. 2010. "Report of the Special Rapporteur on Extra-judicial, Summary or Arbitrary Executions, Philip Alston. Addendum. Study on Targeted Killings." A/HRC/14/24/ Add.6. New York: United Nations. http://www2.ohchr.org/english/bodies/hrcouncil/ docs/14session/A.HRC.14.24.Add6.pdf (accessed March 15, 2013).

UNDP (United Nations Development Programme). 1994. Human Development Report 1994. New York: UNDP.

U.S. Senate. 2013. "Open Hearing on the Nomination of John O. Brennan to be Director of the Central Intelligence Agency." February 7. Washington, D.C.: United States Senate, Select Committee on Intelligence. http://www.intelligence.senate.gov/130207/ transcript.pdf (accessed July 31, 2014).

Whitlock, Craig. 2013. "Drone Base in Niger Gives U.S. a Strategic Foothold in West Africa." Washington Post, March 21. 
Astri Suhrke is Senior Researcher at the Christian Michelsen Institute, Bergen (Norway) and Visiting Fellow, Asia-Pacific College of Diplomacy, The Australian National University. She has written widely on the politics and policies of humanitarian action. Her most recent books are When More is Less: The International Project in Afghanistan (Hurst \& Co. and Columbia University Press, 2011) and The Peace in Between: Post-war Violence and Peacebuilding (co-edited with Mats Berdal) (Routledge, 2012). She first wrote about human security in an article entitled "Human Security and the Interests of States," published in Security Dialogue (1999). E-mail: Astri.Suhrke@cmi.no 